\title{
KAJIAN TEKNIK BIO-INVIGORASI BENIH DAN LEISA UNTUK MENINGKATKAN PERTUMBUHAN PADI GOGO LOKAL PADA SKALA RUMAH KASA
}

\section{ANALYSIS OF SEED BIO-INVIGORATION TECHNIQUE AND LEISA TO INCREASE THE GROWTH OF LOCAL UPLAND RICE AT SCREEN HOUSE}

\author{
Sri Wangadi ${ }^{1 *}$ Gusti Ayu Kade Sutariati $^{2}$ Andi Khaeruni ${ }^{2}$ \\ ${ }^{1)}$ Alumni Program Studi Agronomi Pascasarjana UHO \\ ${ }^{2)}$ Dosen Program Studi Agronomi Pascasarjana UHO
}

Diterima: 15 Desember 2017/Disetujui: 23 Juli 2018

\begin{abstract}
The study aimed to analyze the effectiveness of seeds bio-invigoration technique and LEISA to increase the growth of upland rice. The study was conducted at Agroteknologi Laboratory and Screen House of Agriculture Faculty Halu Oleo University Kendari from July 2015 until February 2016. The study used a completely randomized design with factorial design consisting of two factors. The first factors is bio-invigoration consisting of control (without application bio-invigoration), ground brick plus Bacillus sp. CKD061 and burned rice husk plus Bacillus sp. CKD061, and second factor is LEISA consisting of control (without application of organic fertilizers plus and In organic fertilizers), organic fertilizer plus full dose, in organic fertilizer full dose, organic fertilizer plus full dose + in organic fertilizer full dose, organic fertilizer plus full dose $+1 / 2$ dose in organic fertilizers and organic fertilizer plus full dose $+1 / 4$ dose in organic fertilizers. The treatment was tested as 18 combined treatment and each treatment was repeated 3 times that are 54 unit testing. Each experiment contained 5 polybag, so that overall there are 270 polybag. Data results were analyzed using analysis of variance method and followed by Duncan 's multiple range test if the real effect on the treatment of $\alpha 0.05$. The results showed that the combined treatment of seed bio-invigorasi and LEISA using ground brick plus Bacillus sp. CKD061 and burned rice husk plus Bacillus sp. CKD061 combined with organic fertilizer plus with dose of 2 ton ha $^{-1}+$ in organic with dose of $200 \mathrm{~kg} \mathrm{ha}^{-1}$ Urea, $150 \mathrm{~kg} \mathrm{ha}^{-1} \mathrm{SP} 36$ and $100 \mathrm{~kg} \mathrm{ha}^{-1} \mathrm{KCL}$ increased plant height ages 6 weeks after planting, leaf number 14 MST, 6 MST leaf area , number of tillers 6 and 10 MST gives better results but not significantly different from the treatment of other interactions except with controls. Influence independently, seed bio-invigorasi with ground brick plus Bacillus sp. CKD061 and burned rice husk plus Bacillus sp. CKD061 gives better results compared with controls, and for influence independently of LEISA, all treatments tested have a similar effect in enhancing the growth of upland rice were significantly different from controls.
\end{abstract}

Keywords: Rizobakteri, Seed Bio-Invigoration, LEISA, Upland Rice

\begin{abstract}
ABSTRAK
Penelitian ini bertujuan untuk mengkaji efektivitas bio-invigorasi benih dan LEISA terhadap peningkatan pertumbuhan dan hasil tanaman padi gogo lokal. Penelitian di laksanakan di Laboratorium Agroteknologi dan di Rumah Kasa Kebun Percobaan Fakultas Pertanian Universitas Halu Oleo mulai Bulan Juli 2015 sampai Bulan Februari 2016. Penelitian ini menggunakan Rancangan Acak Lengkap (RAL) dengan pola faktorial yang terdiri dua faktor. Faktor pertama yaitu bio-invigorasi yang terdiri dari kontrol (tanpa aplikasi bio-invigorasi), serbuk bata merah + Bacillus sp. CKD061 dan serbuk arang sekam + Bacillus sp. CKD061. Sementara faktor kedua adalah LEISA yang terdiri dari kontrol (tanpa aplikasi pupuk organik plus dan anorganik), pupuk organik plus dosis full, pupuk anorganik dosis full, pupuk organik plus dosis full + pupuk anorganik dosis full, pupuk organik plus dosis $f u l l+1 / 2$ dosis pupuk anorganik serta pupuk organik plus dosis full $+1 / 4$ dosis pupuk anorganik. Perlakuan yang diuji sebanyak 18 kombinasi percobaan dan setiap perlakuan diulang 3 kali sehingga terdapat 54 unit percobaan. Setiap unit percobaan terdapat 5 polibeg sehingga keseluruhan terdapat 270 polibeg. Data hasil pengamatan dianalisis menggunakan metode analisis ragam dan dilanjutkan dengan uji jarak berganda Duncan jika perlakuan berpengaruh nyata pada $\alpha 0,05$. Hasil penelitian menunjukkan bahwa interaksi perlakuan bio-invigorasi benih dan LEISA menggunakan serbuk bata merah atau arang sekam yang dikombinasikan dengan pupuk organik plus dosis 2 ton ha ${ }^{-1}+$ pupuk anorganik dengan dosis $200 \mathrm{~kg} \mathrm{ha}^{-1}$ Urea, $150 \mathrm{~kg} \mathrm{ha}^{-1}$ SP36 dan $100 \mathrm{~kg} \mathrm{ha}^{-1} \mathrm{KCL}$ memberikan
\end{abstract}

\footnotetext{
${ }^{*}$ Penulis untuk korespondensi. Email : sriwangadi277@yahoo.com
} 


\section{J. Berkala Penelitian Agronomi 6 (2) : 1 - 10 (2018)}

peningkatan tinggi tanaman umur 6 dan 12 MST, jumlah daun 8-14 MST, luas daun 6-12 MST dan jumlah anakan 6 dan 10 MST, yang lebih baik namun tidak berbeda nyata dengan perlakuan lainnya kecuali dengan kontrol, sementara itu, untuk pengaruhnya secara mandiri, bio-invigorasi benih serbuk bata merah + Bacillus sp. CKD061 atau serbuk arang sekam + Bacillus sp. CKD061 memberikan hasil yang lebih baik dibandingkan dengan kontrol, dan untuk LEISA, (semua perlakuan yang diuji kecuali kontrol) memberikan efek yang sama dalam meningkatkan pertumbuhan dan hasil padi gogo.

Kata Kunci: Rizobakteri, Bio-Invigorasi benih, LEISA, Padi gogo

\section{PENDAHULUAN}

Padi (Oryza sativa L.) merupakan komoditas pangan penting di Indonesia karena beras hingga saat ini masih menjadi salah satu bahan pangan bagi sebagian besar masyarakat Indonesia. Potensi pengembangan padi gogo di Sulawesi Tenggara masih terbuka dan terdapat hampir 600.000 ribu hektar lahan kering yang dapat dikembangkan untuk padi gogo. Luas panen padi gogo pada tahun 2014 seluas 6.858 ha dengan produksi 21.589 ton dan hasil $31 \mathrm{kw} \mathrm{ha}^{-1}$ (BPS, 2014). Menurut Sadimantara et al., (2009) kontribusi padi gogo terhadap luas pertanaman padi di Sulawesi Tenggara baru sebesar $10 \%$ dari total penanaman padi yang ada.

Sulawesi Tenggara memiliki luas lahan kering yang sangat potensial dan belum termanfaatkan secara optimal. Padi gogo memiliki potensi untuk mendukung peningkatan produksi padi nasional. Kendala utama pengembangan padi gogo di Sulawesi Tenggara adalah terkait dengan masalah penggunaan benih yang tidak bermutu baik, karena petani kita pada umumnya belum memahami teknik budidaya yang benar, seperti penyediaan benih bermutu atau penggunaan benih tanpa adanya perlakuan pada benih tersebut, sehingga mengakibatkan penurunan hasil tanaman. Selain penggunaan benih yang berkualitas, keberhasilan peningkatan produksi tanaman juga tidak terlepas dari aplikasi pemupukan untuk kebutuhan hara tanaman.

Diperlukan suatu perlakuan khusus untuk mengatasi masalah benih-benih yang bermutu rendah seperti menerapkan teknik bio-invigorasi, karena untuk mendapatkan mutu benih yang baik, persiapan dan perlakuan benih sebelum tanam sangat penting untuk dilakukan. Invigorasi benih adalah perbaikan fisiologis dan biokimiawi yang berhubungan dengan kecepatan, keserempakan berkecambah, perbaikan serta peningkatan kemampuan berkecambah benih yang dapat juga dilakukan dengan media berpotensial matriks rendah atau media matriconditioning. Integrasi perlakuan rizobakteri dan matriconditioning disebut biomatriconditioning yang bertujuan untuk meningkatkan viabilitas benih, pertumbuhan dan hasil tanaman.

Teknik bio-invigorasi yang diintegrasikan dengan agensia hayati kelompok rizobakteri terbukti mampu meningkatkan mutu benih. Teknik invigorasi benih yang diintegrasikan dengan rizobakteri $\begin{array}{lll}\text { B.polymixa } & \mathrm{BG} 25 \quad \text { (Biomatriconditioning }\end{array}$ menggunakan serbuk gergaji) mampu meningkatkan viabilitas dan vigor benih kedelai (Sutariati et al., 2009). Hasil penelitian Sutariati dan Khaeruni (2013) menunjukkan bahwa pemanfaatan Bacillus sp. CKD061 yang diintegrasikan dengan matriconditioning serbuk bata merah dan serbuk arang sekam mampu meningkatkan hasil yang lebih tinggi dan lebih efektif dalam meningkatkan pertumbuhan dan hasil sorgum dibandingkan dengan kontrol. Bacillus sp. CKD061 merupakan bakteri gram positif yang memiliki lapisan dinding sel peptodoglikan lebih tebal daripada bakteri gram negatif. Perlakuan Bacillus sp. CKD061 dengan kombinasi serbuk bata merah menunjukkan kinerja terbaik dibandingkan perlakuan lainnya terutama pada tinggi tanaman, diameter batang, hasil per tanaman, dan indeks panen.

Pemberian pupuk organik tidak efisien karena kandungan hara yang rendah dari pupuk organik, sehingga diperlukan kombinasi dari pupuk kimia, pupuk organik dan pupuk hayati melalui pendekatan terpadu dengan pertanian berkelanjutan yang dapat dijumpai pada konsep Low External Input Sustainable Agriculture (LEISA). LEISA mengacu pada bentuk-bentuk usahatani yang berusaha mengoptimalkan pemanfaatan sumberdaya lokal yang ada. LEISA tidak bertujuan untuk memaksimalkan produksi dalam jangka pendek namun untuk mencapai tingkat produksi yang stabil dan memadai dalam jangka panjang. Pupuk yang digunakan dalam bercocok tanam sebaiknya dikombinasikan antara pupuk organik dan pupuk anorganik. Pemberian pupuk organik (pupuk kandang atau kompos), dapat memperbaiki sifat fisik dan biologi tanah. Sedangkan pemberian pupuk anorganik yang dapat menyediakan hara dalam waktu cepat, pada dosis yang sesuai kebutuhan tanaman akan memberikan pertumbuhan yang positif dan dapat memberikan hasil yang optimal.

Penggunaan benih bermutu dan usaha untuk mengkombinasikan pupuk organik dan anorganik yang diterapkan pada tanaman padi gogo akan memberikan peluang untuk meningkatkan produksi secara berkelanjutan, untuk itu diperlukan suatu teknik dalam meningkatkan pertumbuhan dan hasil 
tanaman yaitu dengan perpaduan antara teknik bioinvigorasi benih dan LEISA yang dapat meningkatkan pertumbuhan padi gogo.

Tujuan yang ingin dicapai pada penelitian ini adalah untuk mengkaji efektivitas teknologi terpadu penggunaan bio-invigorasi benih dan LEISA terhadap pertumbuhan tanaman padi gogo lokal

\section{BAHAN DAN METODE}

Penelitian ini dilaksanakan di Laboratorium Agroteknologi Unit Agronomi dan di Rumah Kasa Kebun Percobaan Fakultas Pertanian Universitas Halu Oleo Kendari. Penelitian berlangsung pada Bulan Juli 2015 sampai dengan Bulan Februari 2016.

Bahan-bahan yang digunakan dalam penelitian ini adalah benih padi gogo lokal kultivar

\section{Tinggi tanaman}

\section{HASIL}

Pengaruh interaksi bio-invigorasi benih dan teknik LEISA terhadap tinggi tanaman padi gogo dapat dilihat pada Tabel 1, sedangkan untuk pengaruh mandirinya dapat dilihat pada Tabel 2 . Interaksi perlakuan antara bio-invigorasi benih dan LEISA menunjukkan bahwa tanpa aplikasi bioinvigorasi dan LEISA (B0L0) memberikan nilai terendah terhadap respons tinggi tanaman pada setiap umur tanaman. Pada umur 6 MST menunjukkan bahwa perlakuan bio-invigorasi serbuk arang sekam
Momea, pupuk organik plus Gaksi, pupuk NPK (Urea, SP-36 dan $\mathrm{KCl}$ ), isolat rizobakteri indigenus Bacillus sp. CKD061 (koleksi Prof. Dr. Ir. Gusti Ayu Kade Sutariati, M.Si), aquades, agar, spiritus, plastik wrap, aluminium foil, kertas label, etanol 70\%, Trypthic Soy Broth (TSB), serbuk arang sekam, serbuk bata merah, sekam, tanah dan polibeg. Alatalat yang digunakan dalam pelaksanaan penelitian ini adalah gelas kimia, botol scott, oven, timbangan analitik, jarum ose, cawan petri, lampu bunsen, autoclave, laminar air flow cabinet, shaker, sekop, gembor, kamera, meteran dan alat tulis menulis .

Data hasil pengamatan dianalisis dengan menggunakan analisis Ragam atau ANOVA. Hasil analisis yang menunjukkan $\mathrm{F}_{\text {hitung }}>\mathrm{F}_{\text {tabel }}$ dilanjutkan dengan Uji Jarak Berganda Duncan (DMRT) pada taraf nyata $\alpha=0.05$.

+ Bacillus sp. CKD061 dengan pemberian pupuk organik plus $+1 / 2$ dosis pupuk anorganik (B2L4) memberikan hasil rerata paling tinggi yang berbeda nyata dengan tanpa aplikasi bio-invigorasi dan pupuk organik plus $+1 / 2$ dosis pupuk anorganik (B0L4), serbuk bata merah + Bacillus sp. CKD061 dan pupuk organik plus $+1 / 2$ dosis pupuk anorganik (B1L4), serbuk arang sekam + Bacillus sp. CKD061 dan tanpa aplikasi pupuk organik plus dan pupuk anorganik (B2L0) serta serbuk arang sekam + Bacillus sp. CKD061 dan pupuk organik plus dosis full (B2L1).

Tabel 1. Pengaruh interaksi antara Bio-invigorasi benih dan LEISA terhadap tinggi tanaman $(\mathrm{cm})$ padi gogo pada umur 6 MST.

\begin{tabular}{|c|c|c|c|c|c|}
\hline Tinggi & Perlakuan & B0 & B1 & B2 & $\begin{array}{l}\text { DMRT } \\
\alpha \\
=0,05\end{array}$ \\
\hline \multirow{6}{*}{6 MST } & LO & $\begin{array}{c}80,00 \mathrm{c} \\
\mathrm{O}\end{array}$ & $\begin{array}{c}84,26 \mathrm{~b} \\
\mathrm{Q}\end{array}$ & $\begin{array}{c}89,64 \mathrm{~b} \\
\mathrm{P}\end{array}$ & \\
\hline & L1 & $\begin{array}{c}82,72 \text { bc } \\
Q\end{array}$ & $\begin{array}{c}89,14 \mathrm{~b} \\
\mathrm{P}\end{array}$ & $\begin{array}{c}91,36 \mathrm{~b} \\
\mathrm{P}\end{array}$ & $2=5,35$ \\
\hline & L2 & $\begin{array}{c}85,23 \mathrm{bc} \\
\mathrm{Q}\end{array}$ & $\begin{array}{c}97,81 \text { a } \\
P\end{array}$ & $\begin{array}{c}96,98 \mathrm{ab} \\
\mathrm{P}\end{array}$ & $3=5,63$ \\
\hline & $\mathbf{L 3}$ & $\begin{array}{c}95,18 \text { a } \\
P\end{array}$ & $\begin{array}{c}96,93 \text { a } \\
P\end{array}$ & $\begin{array}{c}96,48 \mathrm{ab} \\
\mathrm{P}\end{array}$ & $4=5,80$ \\
\hline & L4 & $\begin{array}{c}86,31 \mathrm{~b} \\
\mathrm{R}\end{array}$ & $\begin{array}{c}93,63 \mathrm{ab} \\
\mathrm{Q}\end{array}$ & $\begin{array}{c}99,74 \text { a } \\
\text { P }\end{array}$ & $5=5,93$ \\
\hline & L5 & $\begin{array}{c}90,38 a b \\
Q\end{array}$ & $\begin{array}{c}87,37 \mathrm{~b} \\
\mathrm{Q}\end{array}$ & $\begin{array}{c}98,08 \mathrm{a} \\
\mathrm{P}\end{array}$ & $6=6,03$ \\
\hline
\end{tabular}

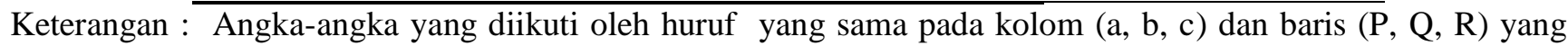
sama menunjukkan tidak berbeda nyata pada DMRT taraf kepercayaan $\alpha=0,05$ 
Hasil DMRT (Tabel 2) menunjukkan nilai tanaman tertinggi terdapat pada perlakuan bioinvigorasi serbuk arang sekam + Bacillus CKD061 (B2) yang berbeda nyata dengan serbuk bata merah + Bacillus CKD061 (B1) dan tanpa aplikasi bioinvigorasi benih (B0) pada pengamatan 2 MST. Pada pengamatan 14 MST, perlakuan B1 dan B2 yang menunjukkan nilai rerata tanaman tertinggi yang berbeda nyata dengan B0, sementara pada pengamatan umur 10 MST tinggi tanaman tertinggi ditunjukkan oleh perlakuan B1 yang berbeda nyata dengan B2 dan B0. Perlakuan mandiri LEISA menunjukkan bahwa perlakuan L1, L2, L3, L4 dan L5 merupakan perlakuan terbaik yang berbeda nyata dengan perlakuan LO.

\section{Jumlah Daun}

Uji rata-rata pengaruh mandiri jumlah daun pada umur 6 MST disajikan pada Tabel 4. Hasil DMRT pengaruh interaksi perlakuan pada pengamatan 14 MST menunjukkan jumlah daun paling sedikit terdapat pada perlakuan tanpa aplikasi kedua faktor perlakuan yang diujikan (BOL0), sedangkan nilai rerata tertinggi pada kombinasi perlakuan serbuk arang sekam + Bacillus sp. CKD061 yang dikombinasikan dengan pupuk organik plus + pupuk anorganik (B2L3) yang berbeda nyata dengan tanpa aplikasi bio-invigorasi dan pupuk organik plus + pupuk anorganik (B0L3), serbuk bata merah + Bacillus sp. CKD061 dan pupuk organik plus + pupuk anorganik (B1L3), serbuk arang sekam + Bacillus sp. CKD061 dan tanpa aplikasi pupuk organik plus maupun pupuk anorganik (B2L0), serbuk arang sekam + Bacillus sp. CKD061 dan hanya dengan pemberian pupuk organik plus (B2L1), serbuk arang sekam + Bacillus sp. CKD061 dan dengan hanya pemberian pupuk anorganik (B2L2) serta serbuk arang sekam + Bacillus sp. CKD061 dan pupuk organik plus $+1 / 2$ dosis pupuk anorganik (B2L4).

Pengaruh mandiri baik bio-invigorasi dan LEISA tidak berpengaruh nyata terhadap jumlah daun pengamatan 2 MST. Hasil DMRT pengaruh mandiri bio-invigorasi pengamatan 6 MST (Tabel 4) menunjukkan nilai tertinggi pada perlakuan bioinvigorasi serbuk arang sekam + Bacillus CKD061 (B2) yang tidak berbeda nyata dengan serbuk bata merah + Bacillus CKD061 (B1), tetapi berbeda nyata dengan tanpa aplikasi bio-invigorasi benih (B0). Pengaruh mandiri LEISA untuk pengamatan 6 MST, hasil tertinggi terdapat pada pemberian pupuk organik plus + pupuk anorganik (L3) yang berbeda nyata dengan hanya pemberian pupuk organik plus (L1) dan tanpa aplikasi keduanya (L0)

Tabel 2. Pengaruh mandiri Bio-invigorasi benih dan LEISA terhadap tinggi tanaman $(\mathrm{cm})$ padi gogo pada umur 2,10 dan 14 MST

\begin{tabular}{lccc}
\hline \multirow{2}{*}{ Perlakuan } & \multicolumn{3}{c}{ Tinggi Tanaman (cm) umur ke - (MST) } \\
\cline { 2 - 4 } Bio-invigorasi & $\mathbf{2}$ & $\mathbf{1 0}$ & $\mathbf{1 4}$ \\
B0 & $30,81 \mathrm{c}$ & $105,17 \mathrm{c}$ & $119,68 \mathrm{~b}$ \\
B1 & $34,28 \mathrm{~b}$ & $119,42 \mathrm{a}$ & $129,20 \mathrm{a}$ \\
B2 & $37,31 \mathrm{a}$ & $115,67 \mathrm{~b}$ & $127,80 \mathrm{a}$ \\
\hline DMRT $\alpha=$ & $2=1,24$ & $2=2,50$ & $2=3,13$ \\
0,05 & $3=1,31$ & $3=2,63$ & $3=3,29$ \\
& & & \\
LEISA & $32,64 \mathrm{~b}$ & $108,34 \mathrm{c}$ & $119,12 \mathrm{~b}$ \\
L0 & $32,86 \mathrm{~b}$ & $113,23 \mathrm{~b}$ & $124,48 \mathrm{a}$ \\
L1 & $34,27 \mathrm{ab}$ & $112,36 \mathrm{~b}$ & $126,89 \mathrm{a}$ \\
L2 & $34,92 \mathrm{a}$ & $113,27 \mathrm{~b}$ & $128,01 \mathrm{a}$ \\
L3 & $35,31 \mathrm{a}$ & $115,48 \mathrm{ab}$ & $128,42 \mathrm{a}$ \\
L4 & $34,80 \mathrm{a}$ & $117,85 \mathrm{a}$ & $126,43 \mathrm{a}$ \\
L5 & $2=1,76$ & $2=3,54$ & $2=4,42$ \\
& $3=1,85$ & $3=3,72$ & $3=4,65$ \\
& $4=1,90$ & $4=3,84$ & $4=4,80$ \\
DMRT & $\alpha=0,05$ & $5=3,92$ & $5=4,90$ \\
& $5=1,95$ & $6=3,99$ & $6=4,98$ \\
\hline
\end{tabular}

Keterangan : Angka-angka yang diikuti oleh huruf yang sama pada kolom (a,b,c) yang sama menunjukkan tidak berbeda nyata pada DMRT taraf kepercayaan $\alpha=0,05$ 
Tabel 3. Pengaruh interaksi antara Bio-invigorasi benih dan LEISA terhadap pengamatan jumlah daun (helai) padi gogo pada umur 10 dan 14 MST.

\begin{tabular}{|c|c|c|c|c|c|c|c|c|}
\hline \multirow{2}{*}{$\begin{array}{c}\text { Jumlah } \\
\text { Daun }\end{array}$} & \multirow[b]{2}{*}{ LEISA } & \multicolumn{5}{|c|}{ Bio-Invigorasi } & & \multirow{2}{*}{$\begin{array}{l}\text { DMRT } \\
\boldsymbol{\alpha}=\mathbf{0 , 0 5}\end{array}$} \\
\hline & & \multicolumn{2}{|c|}{ B0 } & \multicolumn{2}{|c|}{ B1 } & \multicolumn{2}{|l|}{ B2 } & \\
\hline \multirow{6}{*}{10 MST } & LO & 28,34 & $b R$ & 30,64 & $c Q$ & 33,11 & $\mathrm{cP}$ & \\
\hline & L1 & 30,21 & $\mathrm{aR}$ & 33,38 & $\mathrm{bQ}$ & 35,09 & $\mathrm{bP}$ & $2=1,58$ \\
\hline & $\mathbf{L} 2$ & 30,58 & $\mathrm{aR}$ & 36,76 & $\mathrm{aP}$ & 35,10 & $\mathrm{bQ}$ & $3=1,67$ \\
\hline & L3 & 31,12 & $\mathrm{aR}$ & 35,21 & abQ & 36,99 & $\mathrm{aP}$ & $4=1,72$ \\
\hline & L4 & 30,21 & $\mathrm{aQ}$ & 35,44 & $\mathrm{abP}$ & 35,22 & $\mathrm{bP}$ & $5=1,75$ \\
\hline & $\mathbf{L 5}$ & 31,89 & $\mathrm{aQ}$ & 34,45 & $\mathrm{bP}$ & 35,53 & $\mathrm{abP}$ & $6=1,78$ \\
\hline \multirow{6}{*}{14 MST } & Lo & 39,01 & bR & 42,76 & $c Q$ & 45,23 & $\mathrm{cP}$ & \\
\hline & L1 & 41,98 & $\mathrm{aR}$ & 45,71 & $\mathrm{bQ}$ & 47,61 & bP & $2=1,58$ \\
\hline & $\mathbf{L} 2$ & 42,35 & $\mathrm{aQ}$ & 49,09 & $\mathrm{aP}$ & 47,62 & bP & $3=1,67$ \\
\hline & $\mathbf{L 3}$ & 42,89 & $\mathrm{aR}$ & 47,53 & abQ & 49,51 & $\mathrm{aP}$ & $4=1,72$ \\
\hline & L4 & 41,98 & $\mathrm{aQ}$ & 47,77 & $\mathrm{abP}$ & 47,74 & $\mathrm{bP}$ & $5=1,76$ \\
\hline & L5 & 43,66 & $\mathrm{aQ}$ & 46,78 & bP & 48,06 & $\mathrm{abP}$ & $6=1,78$ \\
\hline
\end{tabular}

Keterangan: Angka-angka yang diikuti oleh huruf yang sama pada kolom $(a, b, c)$ dan baris $(P, Q, R)$ yang sama menunjukkan tidak berbeda nyata pada DMRT taraf kepercayaan $\alpha=0,05$.

Tabel 4. Pengaruh mandiri Bio-invigorasi benih dan LEISA terhadap jumlah daun (helai) tanaman padi gogo pada umur 6 MST.

\begin{tabular}{lcc}
\hline \multirow{2}{*}{ Perlakuan } & \multicolumn{3}{c}{ Jumlah Daun (Helai) } \\
\cline { 2 - 3 } & \multicolumn{3}{c}{ DMRT $\alpha=$} \\
Bio-invigorasi & $\alpha, 05$ \\
B0 & $12,53 \mathrm{~b}$ & $2=1,62$ \\
B1 & $13,77 \mathrm{a}$ & $3=1,70$ \\
B2 & $14,06 \mathrm{a}$ & \\
\hline Leisa & & \\
L0 & $12,11 \mathrm{c}$ & $2=0,93$ \\
L1 & $13,08 \mathrm{~b}$ & $3=0,98$ \\
L2 & $13,98 \mathrm{ab}$ & $4=1,01$ \\
L3 & $14,28 \mathrm{a}$ & $5=1,03$ \\
L4 & $13,46 \mathrm{ab}$ & $6=1,05$ \\
L5 & $13,79 \mathrm{ab}$ & \\
\hline
\end{tabular}

\section{Luas Daun}

Pengamatan menunjukkan luas daun yang terkecil terdapat pada perlakuan B0L0 yaitu tanpa aplikasi bio-invigorasi dan LEISA. Pada pengamatan 6 dan 10 MST untuk daun terluas terdapat pada perlakuan serbuk bata merah + Bacillus sp. CKD061 dan pupuk organik plus + pupuk anorganik (B1L3) yang berbeda nyata dengan tanpa aplikasi bioinvigorasi dengan pemberian pupuk organik plus + pupuk anorganik (B0L3), serbuk arang sekam + Bacillus sp. CKD061 dengan pemberian pupuk organik plus + pupuk anorganik (B2L3), serbuk bata merah + Bacillus sp. CKD061 dengan tanpa pemberian pupuk organik maupun anorganik (B1L0), serbuk bata merah + Bacillus sp. CKD061 dengan pupuk organik (B1L1), serbuk bata merah + Bacillus sp. CKD061 dengan pupuk anorganik (B1L2), serbuk bata merah + Bacillus sp. CKD061 dengan pupuk organik plus $+1 / 2$ dosis pupuk 


\section{J. Berkala Penelitian Agronomi 6 (2) : 1 - 10 (2018)}

anorganik (B1L4) serta serbuk bata merah + Bacillus

pupuk anorganik (B1L5) (pengamatan 6 MST).

sp. CKD061 dengan pupuk organik plus $+1 / 4$ dosis

Tabel 5. Pengaruh interaksi antara Bio-invigorasi benih dan LEISA terhadap luas daun $\left(\mathrm{cm}^{2}\right)$ tanaman padi gogo pada umur 6 dan 10 MST.

\begin{tabular}{|c|c|c|c|c|c|}
\hline \multirow{2}{*}{$\begin{array}{l}\text { Luas } \\
\text { Daun }\end{array}$} & \multirow[b]{2}{*}{ LEISA } & \multicolumn{3}{|c|}{ Bio-Invigorasi } & \multirow{2}{*}{$\begin{array}{l}\text { DMRT } \\
\boldsymbol{\alpha}=\mathbf{0 , 0 5}\end{array}$} \\
\hline & & B0 & B1 & B2 & \\
\hline \multirow{6}{*}{6 MST } & LO & 43,98 с Q & $59,97 \mathrm{~d} P$ & $62,10 \mathrm{~d} P$ & \\
\hline & L1 & 51,59 b Q & 64,70 с P & 67,27 c P & $2=3,36$ \\
\hline & $\mathbf{L} 2$ & 57,84 a Q & 72,81 b P & 71,13 b P & $3=3,53$ \\
\hline & L3 & 58,97 a R & 77,66 a $\mathrm{P}$ & 69,03 bc Q & $4=3,64$ \\
\hline & L4 & 60,47 a Q & $72,30 \mathrm{~b} P$ & 73,72 ab P & $5=3,72$ \\
\hline & L5 & 61,46 a Q & 72,65 b P & 75,60 a $\mathrm{P}$ & $6=3,78$ \\
\hline \multirow{6}{*}{$\begin{array}{l}10 \\
\text { MST }\end{array}$} & L0 & 78,17 d Q & 82,93 b P & $82,66 \mathrm{cP} \mathrm{Q}$ & \\
\hline & L1 & 82,76 c Q & 93,22 a $\mathrm{P}$ & 85,84 bc Q & $2=3,65$ \\
\hline & $\mathbf{L 2}$ & 84,67 bc Q & 93,93 a $\mathrm{P}$ & $85,90 \mathrm{bc} Q$ & $3=3,85$ \\
\hline & $\mathbf{L 3}$ & 91,86 a P & 94,60 a $\mathrm{P}$ & 87,43 b Q & $4=3,96$ \\
\hline & L4 & 87,34 b Q & 92,93 a $\mathrm{P}$ & $89,63 \mathrm{ab}$ PQ & $5=4,05$ \\
\hline & L5 & $84,51 \mathrm{bc} Q$ & 94,30 a P & 91,70 a P & $6=4,11$ \\
\hline
\end{tabular}

Keterangan : Angka-angka yang diikuti oleh huruf yang sama pada kolom (a,b,c) dan baris (P,Q,R) yang sama menunjukkan tidak berbeda nyata pada DMRT taraf kepercayaan $\alpha=0,05$.

Tabel 6. Pengaruh mandiri Bio-invigorasi benih dan LEISA terhadap luas daun $\left(\mathrm{cm}^{2}\right)$ tanaman padi gogo pada umur 2 dan 14 MST.

\begin{tabular}{|c|c|c|}
\hline \multirow{2}{*}{ Faktor } & \multicolumn{2}{|c|}{ Luas Daun (cm) umur ke - (MST) } \\
\hline & 2 & 14 \\
\hline \multicolumn{3}{|l|}{ Bioinvigorasi } \\
\hline B0 & $10,66 \mathrm{~b}$ & $99,11 \mathrm{~b}$ \\
\hline B1 & $12,41 \mathrm{a}$ & $105,85 \mathrm{a}$ \\
\hline $\mathrm{B} 2$ & $12,79 \mathrm{a}$ & $105,34 \mathrm{a}$ \\
\hline DMRT $\alpha=$ & $2=1,96$ & $2=1,21$ \\
\hline 0,05 & $3=2,06$ & $3=1,27$ \\
\hline \multicolumn{3}{|l|}{ Leisa } \\
\hline L0 & $10,75 \mathrm{~b}$ & $97,78 \mathrm{c}$ \\
\hline L1 & $11,89 \mathrm{ab}$ & $103,49 \mathrm{~b}$ \\
\hline L2 & $12,10 \mathrm{a}$ & $103,54 \mathrm{~b}$ \\
\hline L3 & $12,57 \mathrm{a}$ & $106,03 \mathrm{a}$ \\
\hline L4 & $12,57 \mathrm{a}$ & $104,77 \mathrm{ab}$ \\
\hline L5 & $11,84 \mathrm{ab}$ & $104,99 \mathrm{ab}$ \\
\hline \multirow{5}{*}{$\begin{array}{l}\text { DMRT } \alpha= \\
0,05\end{array}$} & $2=1,13$ & $2=1,71$ \\
\hline & $3=1,19$ & $3=1,80$ \\
\hline & $4=1,23$ & $4=1,86$ \\
\hline & $5=1,25$ & $5=1,90$ \\
\hline & $6=1,27$ & $6=1,93$ \\
\hline
\end{tabular}

Keterangan : Angka-angka yang diikuti oleh huruf yang sama pada kolom yang sama menunjukkan tidak berbeda nyata pada DMRT taraf kepercayaan $\alpha=0,05$.

Perlakuan mandiri bio-invigorasi benih pada pengamatan 2 dan 14 MST (Tabel 6) masing-masing perlakuan B1 dan B2 menunjukkan berbeda nyata dengan kontrol yaitu tanpa aplikasi bio-invigorasi (B0). Pengaruh mandiri LEISA pada pengamatan 2 MST nilai rataan tertinggi untuk luas daun terdapat 
pada perlakuan pupuk organik plus + pupuk anorganik (L3) yang tidak berbeda nyata dengan perlakuan lainnya kecuali dengan kontrol (L0). Pengamatan umur 14 MST, daun terluas juga

\section{Jumlah anakan (anakan)}

Uji rata-rata pengaruh interaksi bioinvigorasi benih dengan teknik LEISA pada umur 6 terdapat pada perlakuan L3 yang tidak berbeda nyata dengan L4 dan L5 dan berbeda nyata dengan L0, L1 dan L2, namun perlakuan L4 dan L5 tidak berbeda nyata juga dengan perlakuan L1 dan L2

dan 10 MST disajikan dalam Tabel 7. Uji rata-rata pengaruh mandiri jumlah anakan pada umur 14 MST disajikan pada Tabel 8.

Tabel 7. Pengaruh interaksi antara Bio-invigorasi dan LEISA terhadap jumlah anakan (anakan) tanaman padi gogo pada umur 6 dan 10 MST.

\begin{tabular}{|c|c|c|c|c|c|}
\hline \multirow{2}{*}{$\begin{array}{l}\text { Jumlah } \\
\text { Anakan }\end{array}$} & \multirow{2}{*}{ LEISA } & \multicolumn{3}{|c|}{ Bio-invigorasi Benih } & \multirow{2}{*}{$\begin{array}{l}\text { DMRT } \\
\boldsymbol{\alpha}=\mathbf{0 , 0 5}\end{array}$} \\
\hline & & B0 & B1 & B2 & \\
\hline \multirow{6}{*}{6 MST } & LO & $1,22 \mathrm{c} \mathrm{P}$ & 1,35 c $\mathrm{P}$ & 1,46 b P & \\
\hline & L1 & $1,52 \mathrm{bc} Q$ & $1,81 \mathrm{~b} \mathrm{P}$ & 1,58 b Q & $2=0,27$ \\
\hline & $\mathbf{L 2}$ & 1,58 b Q & 2,12 a $\mathrm{P}$ & $1,62 \mathrm{~b} \mathrm{Q}$ & $3=0,28$ \\
\hline & $\mathbf{L 3}$ & $1,54 \mathrm{~b} Q$ & $2,06 \mathrm{ab} \mathrm{P}$ & 1,87 a $\mathrm{P}$ & $4=0,29$ \\
\hline & L4 & 1,49 bc $Q$ & 1,87 b P & $1,81 \mathrm{ab} \mathrm{P}$ & $5=0,30$ \\
\hline & L5 & 1,81 a $\mathrm{P}$ & $1,77 \mathrm{~b} \mathrm{P}$ & $1,65 \mathrm{ab} P$ & $6=0,30$ \\
\hline \multirow{6}{*}{10 MST } & LO & 3,77 a $\mathrm{Q}$ & $4,01 \mathrm{c} \mathrm{Q}$ & 5,72 a $\mathrm{P}$ & \\
\hline & L1 & 4,10 a Q & $5,89 \mathrm{~b} \mathrm{P}$ & 5,67 a $\mathrm{P}$ & $2=1,08$ \\
\hline & $\mathbf{L 2}$ & 4,67 a $Q$ & 6,22 b P & 5,57 a $\mathrm{P}$ & $3=1,14$ \\
\hline & $\mathbf{L 3}$ & 4,53 a $\mathrm{R}$ & 7,44 a $\mathrm{P}$ & 6,23 a Q & $4=1,17$ \\
\hline & L4 & 4,46 a Q & $6,43 a b P$ & 5,67 a $\mathrm{P}$ & $5=1,20$ \\
\hline & $\mathbf{L 5}$ & 4,67 a $Q$ & $6,10 \mathrm{~b} \mathrm{P}$ & 5,67 a PQ & $6=1,22$ \\
\hline
\end{tabular}

Keterangan : Angka-angka yang diikuti oleh huruf yang sama pada kolom $(a, b, c)$ dan baris $(\mathrm{P}, \mathrm{Q}, \mathrm{R})$ yang sama menunjukkan tidak berbeda nyata pada DMRT taraf kepercayaan $\alpha=0,05$.

Pengaruh interaksi pada umur 6 MST, jumlah anakan terbanyak terdapat pada perlakuan kombinasi serbuk bata merah + Bacillus sp. CKD061 dan pupuk anorganik (B1L2) yang berbeda nyata dengan tanpa aplikasi bio-invigorasi dengan pupuk anorganik (B0L2), serbuk arang sekam + Bacillus sp. CKD061 dan pupuk anorganik (B2L2), serbuk bata merah + Bacillus sp. CKD061 dan tanpa aplikasi pemupukan (B1L0), serbuk bata merah + Bacillus sp. CKD061 dan pemberian pupuk organik plus (B1L1), serbuk bata merah + Bacillus sp. CKD061 dan pupuk organik plus $+1 / 2$ dosis pupuk anorganik (B1L4) serta serbuk bata merah + Bacillus sp. CKD061 dengan pemberian pupuk organik plus $+1 / 4$ dosis pupuk anorganik (B1L5), sedangkan pada pengamatan 10 MST, perlakuan kombinasi serbuk bata merah + Bacillus sp. CKD061 dengan pemberian pupuk organik plus + pupuk anorganik (B1L3) yang memberikan jumlah anakan terbanyak.

Tabel 8. Pengaruh mandiri Bio-invigorasi benih dan LEISA terhadap jumlah (anakan) tanaman padi gogo pada umur 14 MST.

\begin{tabular}{lc}
\hline \multirow{2}{*}{ Faktor } & Jumlah anakan (anakan) umur ke - (MST) \\
\cline { 2 - 2 } & 14 \\
\hline Bioinvigorasi & \\
B0 & $8,14 \mathrm{~b}$ \\
B1 & $9,32 \mathrm{a}$ \\
B2 & $9,26 \mathrm{a}$ \\
\hline DMRT $\alpha=$ & $2=1,38$ \\
\hline
\end{tabular}




\begin{tabular}{ll}
0,05 & $3=1,45$ \\
\hline Leisa & \\
L0 & $7,77 \mathrm{~b}$ \\
L1 & $8,90 \mathrm{a}$ \\
L2 & $8,88 \mathrm{a}$ \\
L3 & $9,56 \mathrm{a}$ \\
L4 & $9,07 \mathrm{a}$ \\
L5 & $9,26 \mathrm{a}$ \\
\hline & $2=0,80$ \\
DMRT $\alpha=$ & $3=0,84$ \\
0,05 & $4=0,86$ \\
& $5=0,88$ \\
\hline
\end{tabular}

Keterangan : Angka-angka yang diikuti oleh huruf yang sama pada kolom yang sama menunjukkan tidak berbeda nyata pada DMRT taraf kepercayaan $\alpha=0,05$

Hasil DMRT pengaruh mandiri bioinvigorasi benih pada pengamatan jumlah anakan umur 14 MST, anakan terbanyak diperoleh pada perlakuan B1 yang tidak berbeda nyata dengan B2 tetapi berbeda nyata dengan kontrol (B0). Pengaruh mandiri LEISA seperti yang terlihat pada tabel

\section{PEMBAHASAN}

Hasil penelitian pertumbuhan padi gogo lokal pada skala rumah kasa menunjukkan hasil yang lebih baik dengan penggunaan perlakuan dibandingkan dengan kontrol. Interaksi perlakuan serbuk arang sekam + Bacillus sp. CKD061 dengan pemberian pupuk organik plus dosis full + pupuk anorganik dosis full memberikan pengaruh yang lebih baik, hal ini disebababkan peran dari rizobakteri dan media matriconditioning yang digunakan. Rizobakteri Bacillus CKD061 merupakan salah satu rizobakteri pemacu tumbuh tanaman yang secara agresif mengolonisasi rizosfer yang dapat memberikan keuntungan bagi pertumbuhan tanaman. Pengaruh secara langsung adalah meningkatkan petumbuhan tanaman dan dapat bertindak sebagai fasilitator dalam penyerapan beberapa unsur hara dari lingkungan, hal ini sesuai dengan hasil penelitian Ashrafuzzaman et al., 2009 yang menyatakan bahwa penggunaan rizobakteri ini efektif dalam memobilisasi unsur hara dalam tanah serta mensintesis hormon pemacu tumbuh tanaman, sedangkan pengaruh dari media matriconditioning yang digunakan mengakibatkan air yang tersedia untuk benih sangat sedikit karena yang menyerap air adalah media tersebut, sehingga benih tidak menyerap air secara bebas dan proses metabolik terjadi secara sempurna karena ada perbaikan- diatas, anakan padi terbanyak diperoleh pada perlakuan pupuk organik plus + pupuk anorganik (L3) pada semua pengamatan umur tanaman yang berbeda nyata dengan tanpa perlakuan pemberian pupuk (L0).

perbaikan yang terjadi selama proses aktivasi yang menyebabkan ketika benih ditanam, benih dapat langsung tumbuh dan menampilkan performa yang lebih baik.

Pemupukan dalam pola LEISA yaitu menggabungkan antara penggunaan pupuk organik dan pupuk anorganik untuk memaksimalkan pertumbuhan tanaman dan meminimalkan penggunaan pupuk kimia yang berlebihan. Pengaruh mandiri untuk pola LEISA dalam penelitian ini umumnya memiliki nilai yang lebih tinggi pada perlakuan pemberian pemupukan dosis full pupuk organik plus + pupuk anorganik yang tidak berbeda nyata dengan perlakuan lainnya kecuali tanpa aplikasi LEISA (kontrol). Dosis pemupukan berbeda yang diberikan mampu menyediakan kebutuhan hara bagi tanaman dalam melangsungkan pertumbuhannya.

Pupuk anorganik mampu memperbaiki tingkat kesuburan tanah. Hal ini sesuai dengan pendapat Hakim (1986) yang menyatakan bahwa untuk menambah ketersediaan unsur hara bagi tanaman maka perlu dilakukan pemupukan. Pemupukan anoganik dengan campuran pupuk organik juga diperlukan karena tingkat kesuburan tanah lahan kering di Sulawesi Tenggara pada umumnya kurang subur dan bersifat masam, sehingga untuk keperluan produksi pangan diperlukan input yang besar, salah satunya dengan 
penggunaan bahan organik tanpa meninggalkan penggunaan pupuk anorganik. Aplikasi pupuk organik plus yang diperkaya dengan pupuk hayati dalam pola LEISA mampu mengurangi aplikasi pupuk anorganik secara tunggal. Pupuk organik sangat dibutuhkan oleh tanaman agar dapat tumbuh secara optimal. Perbaikan pertumbuhan yang ditimbulkan dari penggunaan pupuk organik plus, tidak terlepas dari peran agensia hayati $(B$. polymixa BG25, P. fluorescens PG01 dan $S$. liquefaciens SG01) yang terkandung di dalamnya. Ketiga jenis agensia hayati tersebut termasuk kelompok Plant Growth Promoting Rhizobacteria (PGPR) yang berperan sebagai pemacu pertumbuhan tanaman (Sutariati, 2006),

Penggunaan rizobakteri dalam bio-invigorasi yaitu Bacillus sp. CKD061 mampu meningkatkan pertumbuhan padi gogo lokal dibandingkan dengan tanpa penggunaan rizobakteri. Hal ini sejalan dengan hasil penelitian Sutariati dan Wahab (2012) menyatakan bahwa rizobakteri dari golongan Bacillus mampu menghasilkan hormon IAA dan melarutkan fosfat. Selain mampu menghasilkan hormon IAA dan melarutkan fosfat, rizobakteri dari golongan Bacillus sp. juga mampu menfiksasi nitrogen (Sutariati, 2006). Hormon IAA yang dihasilkan rizobakteri mampu memacu perkecambahan benih sehingga mengakibatkan percepatan perkecambahan benih padi gogo. Khaeruni et al. (2014), melaporkan bahwa formulasi rizobakteri pada benih waktu pengamatan 2 dan 4 minggu setelah tanam, efektif meningkatkan pertumbuhan tinggi tanaman dan jumlah daun sebesar $119 \%$ dan $170 \%$.

Perlakuan bio-invigorasi benih dan pemupukan dalam pola LEISA berpengaruh sangat nyata pada tinggi tanaman pengamatan umur 6 MST yaitu dengan perlakuan bio-invigorasi serbuk arang sekam + Bacillus CKD061 dan kombinasi pupuk organik plus masing-masing $1 / 2$ dan $1 / 4$ dosis pupuk anorganik, sedangkan pada pengamatan jumlah daun umur 10 MST, daun yang terbanyak adalah dengan perlakuan B2L3 yaitu kombinasi serbuk arang sekam + Bacillus sp. CKD061 yang diberikan pemupukan

\section{DAFTAR PUSTAKA}

Ashrafuzzaman, M., F. A. Hossen, M. R. Ismail, Md. A. Hoque, M. Z. Islam, S.M. Shahidullah, dan S. Meon. 2009. Efficiency of plant growthpromoting rhizobacteria (PGPR) for the enhancement of rice growth. African Journal of Biotechnology. Vol 8 No. 7 p. 1247-1252.

BPS SULTRA. 2014. Sultra dalam Angka. Kendari. Hakim, N. 1986. Dasar-Dasar Ilmu Tanah, Universitas Lampung. Lampung. organik plus dan anorganik, tetapi perlakuan tersebut tidak berbeda nyata juga dengan perlakuan B2L5. Hal ini sejalan dengan penelitian Sutariati et al., (2014) yang menyatakan bahwa dengan pola kombinasi pupuk organik dan pupuk anorganik separuh dosis anjuran mampu meningkatkan pertumbuhan dan hasil bawang merah, hal ini lebih disebabkan oleh dosis yang diberikan telah mampu menyediakan kebutuhan unsur hara bagi tanaman dalam melangsungkan pertumbuhan terutama fase vegetatf.

\section{KESIMPULAN}

Berdasarkan hasil dan pembahasan, maka dapat disimpulkan bahwa Interaksi perlakuan bioinvigorasi benih dan LEISA berpengaruh terhadap pertumbuhan padi gogo lokal yang ditunjukkan dengan peningkatan tinggi tanaman, jumlah daun, luas daun dan jumlah anakan. Teknik bio-invigorasi benih serbuk bata merah + Bacillus sp. CKD061 atau serbuk arang sekam + Bacillus sp. CKD061, secara mandiri memberikan hasil yang lebih baik dalam meningkatkan pertumbuhan padi gogo lokal dibandingkan dengan kontrol. Teknik LEISA secara mandiri (semua perlakuan yang diuji kecuali kontrol) memberikan efek yang sama dalam meningkatkan padi gogo.

Interaksi perlakuan bio-invigorasi benih dan LEISA menggunakan serbuk bata merah atau arang sekam yang dikombinasikan dengan pupuk organik plus dosis 2 ton ha ${ }^{-1}+$ pupuk anorganik dengan dosis $200 \mathrm{~kg} \mathrm{ha}^{-1}$ Urea, $150 \mathrm{~kg} \mathrm{ha}^{-1}$ SP36 dan $100 \mathrm{~kg} \mathrm{ha}^{-1}$ $\mathrm{KCl}$ memberikan peningkatan tinggi tanaman umur 6 MST, jumlah daun 14 MST, luas daun 6 dan 10 MST dan jumlah anakan 6 dan 10 MST yang lebih baik namun tidak berbeda nyata dengan perlakuan interaksi lainnya kecuali dengan tanpa perlakuan (kontrol).

Disarankan menggunakan perlakuan LEISA pupuk organik plus $+1 / 4$ dosis pupuk anorganik agar budidaya tanaman padi gogo lebih ramah lingkungan dan perlu penelitian lanjutan menggunakan perlakuan terbaik dalam percobaan skala lapangan.

Khaeruni A, Asniah, Taufik M., dan Sutariati GAK, 2014. Aplikasi formula campuran rizobakteri untuk pengendalian penyakit busuk akar Rhizoctonia dan peningkatan hasil kedelai di tanah ultisol. Jurnal Fitopatologi, Vol. 10 No. 2 p. $37-44$.

Sadimantara, G.R, Leomo, S., Suliartini, N.W.S., dan Jaya M., 2009. Perakitan Padi Gogo Unggul Lokal Berpotensi Produksi Tinggi dan Tahan terhadap Cekaman Lingkungan. Laporan 
Pelaksanaan Penelitian Intensif Riset Unggulan Strategis Nasional. Kendari.

Sutariati, GAK. 2006. Perlakuan Benih dengan Agens Biokontrol untuk Pengendalian Penyakit Antraknosa, Peningkatan Hasil dan Mutu Benih Cabai. Disertasi, Program Pascasarjana Institut Pertanian Bogor.

Sutariati, G.A.K., Khaeruni, A dan Madiki, A. 2009. Integrasi Teknik Invigorasi Benih Plus Agens Hayati untuk Peningkatan Hasil dan Mutu Benih Tanaman Kedelai. Prosiding Seminar Nasional "Inovasi untuk Petani dan Peningkatan Daya Saing Produk Pertanian", Balai Pengkajian Teknologi Pertanian Jawa Timur dengan FEATI dan Dinas Pertanian Propinsi Jawa Timur.

Sutariati, G.A.K dan A. Wahab. 2012. Kararkter fisiologis dan kemangkusan rizobakteri indigenus sebagai pemacu pertumbuhan Tanaman Cabai. J. Hotikultura, Vol. 22 No. 1, p. 57-64.

Sutariati, GAK dan Khaeruni A., 2013. Seed biomatriconditioning using rhizobacteria for growth promotion and increase the yield of sorghum (Sorghum bicolor (L.) Moench) on marginal soil, Agricultural Science Research Journals, Vol. 3 No. 3 p. 85-92.

Sutariati, GAK, Leomo, S dan Rakian, TC., 2014. Keragaan pertumbuhan dan hasil bawang merah (Allium ascalonicum L.) pada berbagai ukuran umbi dan teknologi LEISA, AGRIPLUS, Vol. 24 No. 1 p. 14-25. 